\title{
Foam mat drying of banana juice: varieties of ripe banana analysis and egg albumen foam
}

\author{
Anna NOORDIA ${ }^{1 *}\left(\mathbb{D}\right.$, Yetty Septiani MUSTAR ${ }^{1}$, Nining Widyah KUSNANIK ${ }^{2}$
}

\begin{abstract}
Drying technologies for ripen bananas is needed. Ripe bananas contains more antioxidant levels, anti-cancerous properties, easier to digest and useful for anxiety and depression. Considering nutrition compositional changes and the effect of external factors during processing ripe banana as a flour, foam mat drying with egg albumen foam was chosen. This research aim to provide an overview of banana juice foam mats from three different varieties bananas at level 5 up to 7 of maturity and mixed into different proportion using egg albumen as foaming agent and dried at temperatures from $60{ }^{\circ} \mathrm{C}$ to $80{ }^{\circ} \mathrm{C}$ in a cabinet dryer to a brittle and porous solid which able to grind. The study revealed that there is a significant difference in combination of banana varieties to rendement, the solubility of the powder and moisture content. The combination of various varieties of bananas is considered better to produce quality of ripen banana flour.
\end{abstract}

Keywords: drying technologies; foaming agent; banana powder; cabinet dryer.

Practical Application: Preventing food waste from overripe bananas to ensure the long-term sustainability of banana used.

\section{Introduction}

Ripe bananas preferred but over ripe bananas are less favored. As an unwanted, the over ripen bananas become discarded (Segundo et al., 2017). The way to diminish this disposal is by making it as flour. Banana flour is a suitable form not only to minimize postharvest losses but also to obtain the nutritive value of fresh bananas (Pragati et al., 2014). Banana flour technology generally use green bananas as raw materials. Drying ripe bananas into flour has certain matter which must have considered. The effect of external factors during processing and the existence of bioactive component require exact drying technologies.

Foam mat drying is one technique used for the production of fruit powders. It can produce high quality and stable particles which can protect natural components and the integrity of the organoleptic characteristics. The foam mat drying method compatible to apply on component with heat sensitive, viscous and high sugar content foods that cannot be dried using other forms of drying methods. This method was invented to a powder that is simply rehydrated and provide organoleptic characteristics such as color, flavor, texture and nutritional contexture which is resembling to the crude material (Fernandes et al., 2013). In this drying method, liquid is transformed into a stable foam by being whipped after addition of an edible foaming agent. The stable foam is dried by applying hot air (Raharitsifa et al., 2006; Rajkumar et al., 2007; Hardy \& Jideani, 2015).

The nutritional characteristic of egg white make them ideal for use as a foaming agent. Egg white, or so-called as an albumin contains about $9.7-10.6 \%$ protein. There are ovalbumin, conalbumin, ovomucoid, ovomucin and lysozyme a glycoprotein, representing about $3.4 \%$ of the egg white's proteins as a major egg white protein. Ovoglobulins G2 and G3, avidin, ovoinhibitor, cystatin, ovoglycoprotein, ovomaroglobulin and ovoflavoprotein were the other minor egg white proteins (Alleoni, 2006). Lysozyme is a glycoprotein and widely being used as food preservative, as naturally bacteriolytic enzyme (Hui \& Al-Holy, 2007). Foaming ability of white egg was determined by globulin, lysozyme, ovomucoid and ovomucin (Damodaran et al., 1998). Globulins are the most surface active egg white protein for foaming ability (Lau \& Dickinson, 2004). It has capability to quickly adsorb the air-water interface during whipping or bubbling and the ability to form a cohesive viscoelastic film by intermolecular interactions between proteins (Mine, 1995; Lomakina \& Mikova, 2016).

\section{Materials and methods}

\subsection{Instrumentation and procedure}

Three varieties of bananas (Kepok Lumajang, Ambon Probolinggo, and Agung Lumajang) at level 5 up to 7 of maturity. The bananas were prepared through washing and peeling them then soaked them for 10 minutes in an aqueous solution containing $5 \mathrm{~mL}$ lime juice. Bananas then are cut into slices and steamed for 10 minutes. Banana juice was made through blending three varieties mix in different proportion $45 \%, 35 \%$ and $20 \%(\mathrm{w} / \mathrm{v})$ with $50^{\circ} \mathrm{C}$ distilled water, which was then filtered to separate the solution and the impurities.

Egg albumen used as a foaming agent. About $500 \mathrm{~mL}$ of banana juice was poured into a mixing bowl added with $3 \%$ (w/w) egg albumen whipped using a hand blender (Philips HR 2116 Hand Blender, Bogor, Indonesia) at speed level 2 
for 5 minutes. The banana juice foam was poured into trays, dimension $22 \times 12 \times 10 \mathrm{~cm}$, with a thickness $2 \mathrm{~mm}$ then dried at a temperature from $60{ }^{\circ} \mathrm{C}$ to $80{ }^{\circ} \mathrm{C}$ in a cabinet dryer to a brittle solid, which was amenable to grind.

Selected properties such as rendement, moisture content using AOAC method (Association of Official Analytical Chemists, 2007), and the water solubility rate of the powder were determined. The rendement was calculated as a percentage by dividing weight of the final product produced with the weight of the processed material. Water solubility rate on banana powder known as duration time for banana powder dissolves completely. $1 \mathrm{~g}$ of material was added to $20 \mathrm{~mL}$ of distilled water and stirred with a magnetic stirrer at $892 \mathrm{rpm}$ (Goula \& Adamopoulos, 2010).

\subsection{Experimental design and statistical analysis}

This experiment used Complete Randomized Design (CRD). Three level combination of varieties banana were used. Details of the experimental design are given in Table 1.

Descriptive statistics were determined for each variable recorded. Data are presented as mean. Normality test measured whether data obtained has a normal distribution so it can be used in parametric statistics. One-way Anova and LSD were applied for statistical evaluation of the data generated using SPSS Version 22. The significance level was put at ' $p$ ' value $<0.05$ with 95\% Confidence Interval (CI).

\section{Results}

The calculation of variance analysis (ANOVA) to the water content, solubility and rendement of banana flour shows that the comparison of three varieties banana in different proportion
(45\%, 35\% and 20\%) alternately showed significant at $\mathrm{p}<0.05$ (Table 2).

The moisture content for foam mat dried banana flour, were at range $11.15 \%$ to $14.68 \%$. Figure 1 shows that banana flour produced by a combination of $45 \%$ Kepok, 20\% Ambon and $35 \%$ Agung has the lowest moisture content. LSD analysis at Table 3 shows that the combination of each treatment showed a marked difference significantly.

Water soluble rate (WSR) of banana flour was from 217-259 second. Figure 1 showed the WSR increased as the moisture content also increased. The LSD analysis combination of P1 and P2 showed that was not significant difference between two group.

The rendement of banana flour produced ranges between 6.7-7.7\% (Figure 2). The LSD results showed that there was not significant difference between P1 with P3.

Table 1. Level combination of banana.

\begin{tabular}{cccc}
\hline Treatment & $\begin{array}{c}\text { Combination of banana } \\
\text { (kepok: ambon: agung) }\end{array}$ & $\begin{array}{c}\text { Foam Agent } \\
\text { (egg albumen) }\end{array}$ & $\begin{array}{c}\text { Water } \\
\text { (gr/mL) }\end{array}$ \\
\hline P1 & $45 \%: 35 \%: 20 \%$ & $3 \%$ & $1: 2$ \\
P2 & $35 \%: 20 \%: 45 \%$ & $3 \%$ & $1: 2$ \\
P3 & $20 \%: 45 \%: 35 \%$ & $3 \%$ & $1: 2$ \\
\hline
\end{tabular}

P1: first banana composition, P2: second banana composition, P3: third banana composition.

Table 2. Analysis of variance of responses for foam mat dried banana flour.

\begin{tabular}{lll}
\hline Variable of Response & $\mathrm{F}$ & $\mathrm{p}_{\text {value }}$ \\
\hline Moisture content & 99.8 & 0.00 \\
Water Solubility Rate & 34.75 & 0.01 \\
Rendement & 13.19 & 0.06 \\
\hline
\end{tabular}

F: variation between sample means, $\mathrm{p}_{\text {value }}$ : mean significance at $p<0.05$.

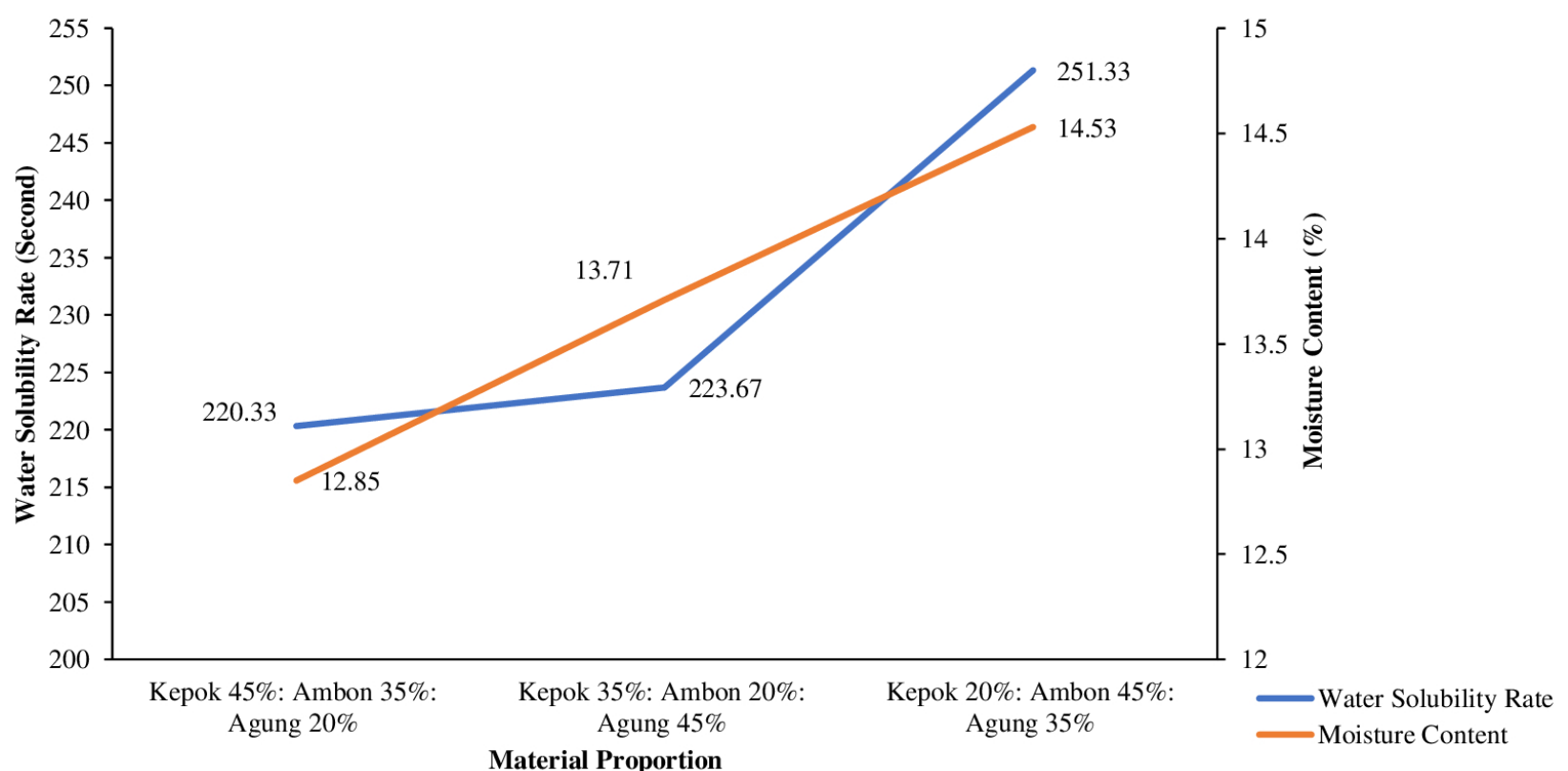

Figure 1. The relevance of moisture content and water solubility rate. 
Table 3. Least Significant Difference (LSD) of foam mat dried banana flour.

\begin{tabular}{|c|c|c|c|c|}
\hline Dependent Variable & Treatment (I) & Treatment $(J)$ & $\begin{array}{c}\text { Mean } \\
\text { Difference (I-J) }\end{array}$ & $\mathrm{p}_{\text {value }}$ \\
\hline \multirow[t]{4}{*}{ Moisture content } & \multirow[t]{2}{*}{ Kepok 45\%: Ambon 35\%: Agung 20\% (P1) } & Kepok 35\%: Ambon 20\%: Agung 45\% & -0.85 & $0.00^{*}$ \\
\hline & & Kepok 20\%: Ambon 45\%: Agung 35\% & -1.67 & $0.00^{*}$ \\
\hline & Kepok 35\%: Ambon 20\%: Agung 45\% (P2) & Kepok 20\%: Ambon 45\%: Agung 35\% & -0.82 & $0.00^{*}$ \\
\hline & Kepok 20\%: Ambon 45\%: Agung 35\% (P3) & Kepok 45\%: Ambon 35\%: Agung 20\% & 1.67 & $0.00^{*}$ \\
\hline \multirow{5}{*}{ Water Solubility Rate } & Kepok 45\%: Ambon 35\%: Agung 20\% (P1) & Kepok 20\%: Ambon 45\%: Agung 35\% & -31.00 & $0.00^{*}$ \\
\hline & \multirow[t]{2}{*}{ Kepok 35\%: Ambon 20\%: Agung 45\% (p2) } & Kepok 45\%: Ambon 35\%: Agung 20\% & 3.33 & 0.44 \\
\hline & & Kepok 20\%: Ambon 45\%: Agung 35\% & -27.6 & $0.00^{*}$ \\
\hline & \multirow[t]{2}{*}{ Kepok 20\%: Ambon 45\%: Agung 35\% (P3) } & Kepok 45\%: Ambon 35\%: Agung 20\% & 31.00 & $0.00^{*}$ \\
\hline & & Kepok 35\%: Ambon 20\%: Agung 45\% & 27.67 & $0.00^{*}$ \\
\hline \multirow{2}{*}{ Rendement } & \multirow[t]{2}{*}{ Kepok 20\%: Ambon 45\%: Agung 35\% (P3) } & Kepok 45\%: Ambon 35\%: Agung 20\% & 0.23 & 0.14 \\
\hline & & Kepok 35\%: Ambon 20\%: Agung 45\% & -0.46 & $0.01^{*}$ \\
\hline
\end{tabular}

Significant: $*$, mean significance at $p<0.05$.

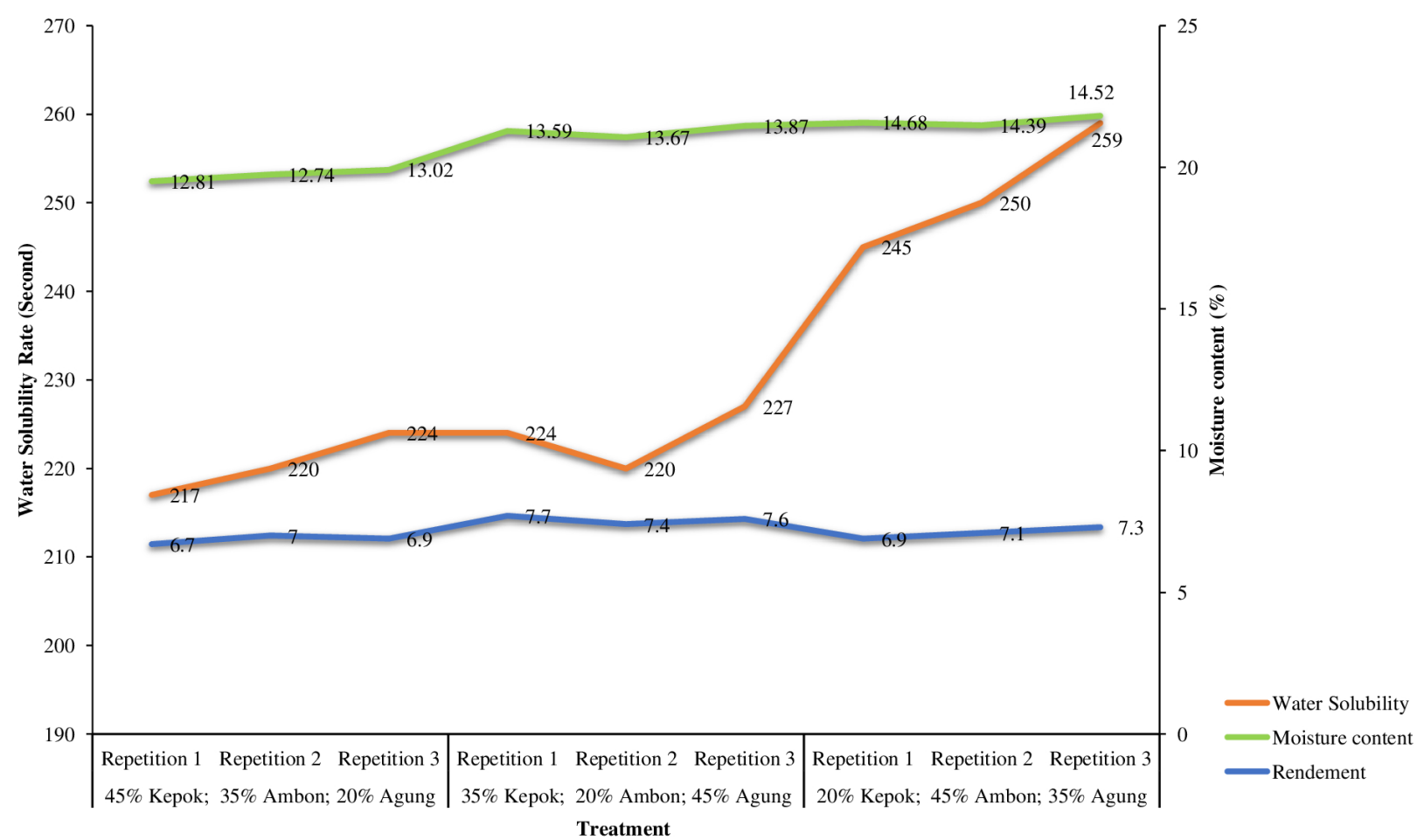

Figure 2. Characteristics of average values of banana combination treatment on rendement, speed and moisture.

\section{Discussion}

Moisture content is an important parameter and should be minimized during the drying process as it relates to product stability. It determines the acceptability, freshness and durability of product. A high level of amylose causes the starch is less adhesive and tends to absorb more water (hygroscopic) and gel formed is sturdy.
The water solubility rate (WSR) is a variable to measure the speed of powder dissolution. The soluble or dispersible powder without clump formation is one of the quality parameters of the product in the form of powder. Powders with high porosity have a larger surface area, so that the contact area between the powder and water become bigger (Pua et al., 2010). 


\section{Conclusion}

Ripe bananas can be made into powder through the method of foam mat drying using an egg whitening agent. The highest result was from combination of $20 \%$ of Kepok bananas, $45 \%$ of Ambon bananas and 35\% of Agung bananas. The lowest water content and the rate of resolubility were obtained from a mixture of $45 \%$ of Kepok banana, 35\% of Ambon bananas, and $20 \%$ of Agung bananas.

\section{Acknowledgements}

Authors wholeheartedly would like to express many thanks to the Research Programme of Kemenristekdikti of Indonesia and Unesa for the facilities, assistance and financial support through the superior colleges research funding.

\section{References}

Alleoni, A. (2006). Albumen protein and functional properties of gelation and foaming. Scientia Agrícola, 63(3), 291-298. http:// dx.doi.org/10.1590/S0103-90162006000300013.

Association of Official Analytical Chemists - AOAC. (2007). Official methods of analysis (18th ed.). Gaithersburg: AOAC.

Damodaran, S., Anand, K., \& Razumovsky, L. (1998). Competitive adsorptionof egg white at the air-water interface: direct evidence forelectrostatic complex formation between lysozyme and other eggproteins at the interface. Journal of Agriculture and Food Chemistry, 46(3):872-876.

Fernandes, R. V. B., Queiroz, F., Botrel, D. A., Rocha, V. V., Lima, C. F., \& Souzafoam, V. R. (2013). Foam mat drying of tomato pulp. Bioscience Journal, 29(4), 819-825.

Goula, A. M., \& Adamopoulos, K. G. A. (2010). A new technique for spray drying orange juice concentrate. Innovative Food Science \& Emerging Technologies, 11(2), 342-351. http://dx.doi.org/10.1016/j. ifset.2009.12.001.
Hardy, Z., \& Jideani, V. A. (2015). Foam-mat drying technology: a review, critical reviews. Food Science and Nutrition, 57(12), 25602572. http://dx.doi.org/10.1080/10408398.2015.1020359.

Hui, Y. H., \& Al-Holy, M. A. (Eds.). (2007). Food chemistry: principles and applications (2nd ed.). West Sacramento: Science Technology System.

Lau, K., \& Dickinson, E. (2004). Structural and rheological properties of aerated high sugar systems containing egg albumen. Journal of Food Science, 69(5), E232-E239.

Lomakina, K., \& Mikova, K. (2016). A study of the factors affecting the foaming properties of egg white: a review. Czech Journal of Food Sciences, 24(3), 110-118. http://dx.doi.org/10.17221/3305-CJFS.

Mine, Y. (1995). Recent advances in the understanding of egg white protein functionality. Trends in Food Science \& Technology, 6(7), 225-232. http://dx.doi.org/10.1016/S0924-2244(00)89083-4.

Pragati, S., Genitha, I., \& Ravish, K. (2014). Comparative study of ripe and unripe banana flour during storage. Journal of Food Processing \& Technology, 5(11), 1000384.

Pua, C. K., Hamid, N. S. A., Tan, C. P., Mirhosseini, H., Rahman, R. B. A., \& Rusul, G. (2010). Optimization of drum drying processing parameters for production of jackfruit (Artocarpus heterophyllus) powder using response surface methodology. Lebensmittel-Wissenschaft + Technologie, 43(2), 343-349. http://dx.doi.org/10.1016/j.lwt.2009.08.011.

Raharitsifa, D. B., Genovese, D. B., \& Ratti, C. (2006). Characterization of apple juice foams for foam-mat drying prepared with egg white protein and methylcellulose. Journal of Food Science, 71(3), E142-E151. http://dx.doi.org/10.1111/j.1365-2621.2006.tb15627.x.

Rajkumar, P., Kailappan, R., Viswanathan, R., \& Raghavan, G. S. V. (2007). Drying characteristics of foamed alphonso mango pulp in a continuous type foam at dryer. Journal of Food Engineering, 79(4), 1452-1459. http://dx.doi.org/10.1016/j.jfoodeng.2006.04.027.

Segundo, C., Román, L., Lobo, M., Martinez, M. M., \& Gómez, M. (2017). Ripe banana flour as a source of antioxidants in layer and sponge cakes. Plant Foods for Human Nutrition, 72(4), 365. http:// dx.doi.org/10.1007/s11130-017-0630-5. PMid:28887738. 